\title{
THE ROLE OF NETWORK CAPABILIITY IN SHAPING BEHAVIOR E-COMMERCE ACCEPTANCE AMONG SMALL BUSINESSES IN KERANGGAN VILLAGE
}

\author{
Yuniarty, Hartiwi Prabowo, Ridho Bramulya Ikhsan \\ Management Department, Binus Online Learning, Bina Nusantara University, West Jakarta, Indonesia \\ yuniarty@binus.ac.id, hartiwi@binus.edu, ridho.bramulya.i@binus.ac.id
}

Received: January $21^{\text {st }}, 2020 /$ Revised: February $12^{\text {th }} 2020 /$ Accepted: February $24^{\text {th }}, 2020$

\begin{abstract}
This research is a case study to help identify the driving factors of e-commerce acceptance by small businesses in Keranggan Village in Indonesia. This study argues that factors such as technologyorganization-environment need to be strengthened by network capability from business actors so that e-commerce adoption intention emerges. From the total samples of 100 business actors in Keranggan Village. The study utilized Structural Equation Modeling (SEM) with SmartPLS 3.0 for data examination. Consequently, the relationship of technological context with e-commerce acceptance is mediated by significant network capability.
\end{abstract}

Keywords: network capability, TOE, e-commerce acceptance, SME, case study

\section{Introductions}

The first reason why MSME (Micro, Small and Medium Enterprises) players take advantage of the digital ecosystem is to expand market reach. The limitations of the distribution and marketing system have always been a major obstacle for small businesses. The constant growth in e-commerce in the preceding years has sparked an expansion in the study of the effects of e-commerce on the mobility system (Bjørgen et al., 2019). A variety of legacy entrepreneurs make efforts to take market opportunities related to transformation and up-gradation (Wei et al., 2018). Going digital, SMEs not only have the potential to gain more customers, but also begin to enter a new stage of competition in the realm of modern industry. The business will get more value from potential customers if SMEs player already have social media and a website as a marketing medium.

Switching from the offline market to the online realm is not as easy as turning your palm. Entering the digital realm means that you must be ready to fill in everything that is caused. For example, such as being alert in answering consumer questions anytime and anywhere, having to master safe packaging techniques so that products can be received in good condition, and the ability to close sales. The adoption of e-commerce is still a major concern for various societies in Indonesia.

The problem faced by small businesses in Keranggan Village is that the limited access to marketing is an obstacle for business actors to develop their business. This is because SMEs are not yet literate in information technology and the low adoption of e-commerce, even though there have been many trainings by cooperatives and local social institutions. The problems experienced by small business operators in Keranggan are a common problem that is also experienced by most small business operators in Indonesia. More than 36 percent of SMEs in Indonesia are still offline, and 37 percent only have very basic online skills such as computers or broadband access, based on data from the Delloite Access Economics Report: SMEs Powering Indonesia success. Only a small proportion or 18 percent have medium online skills, namely using the web or 
social media. Even though less than 9 percent are developed online businesses with ecommerce capabilities. In addition, Deputy for Access to Capital at the Creative Economy Agency (Bekraf) Fadjar Hutomo at www.wcce.id said digital media plays an important role in all aspects of people's lives today, including in the SME trade sector.

In current years, many scientific articles associated to the e-commerce adoption are growing. Traditional adoption theories such as reasoned action theory dan planned behavior theory (Ajzen, 1991; Ajzen \& Madden, 1986), technology acceptance models (Davis, 1989) the diffusion theory of innovation (Rogers, 2003), and the integrated theory of technology acceptance and use (UTAUT) (Venkatesh et al., 2003), are almost techno-centric and as such, address individual-level adoption, whereas TOE (Tornatzky et al., 1990) and technology-organization-environment decision makers focus more on organizational-level factors.

TOE factors are commonly used by previous research to identify factors driving the adoption of information technology (Alsaad et al., 2019; Mukred et al., 2018, 2019; Singh \& Mansotra, 2019; Ziba \& Kang, 2019). Thus, this research benefits in twofold. Primary, we contribute to identify the factors that encourage businesses in Keranggan to adopt ecommerce. The model combined TOE factors (Tornatzky et al., 1990) with the network capability construct (Mu et al., 2017), for better understanding of the e-commerce adoption phenomena. This study argues that factors such as technology-organizationenvironment need to be strengthened by network capability from business actors so that e-commerce adoption intention emerges. network capability in business will foster innovation, build collaboration, cut business costs, solve problems and be useful for business development. The article resolves by an analysis of theoretical implications and guidance for SMEs.

\section{Methods}

Some researchers have identified technology as a crucial factor for achieving successful information system adoption (Kuan \& Chau,
2001), (Chang, 2010), (DeLone \& McLean, 2003). The CEOs who execute e-commerce adoption altogether accept that e-commerce able to extend deals, extend market share, diminish costs, create new business prospects (Sin et al., 2016), (Olatokun \& Kebonye, 2010), (Alamro \& Tarawneh, 2011). Organizational factors is measured through scope factors and organizational structure and was elaborated with indicators of organizational readiness, among others: the range of markets served, the reach of distribution channels, the ability of alliances with suppliers, customer relations ( $\mathrm{Zhu}$ et al., 2002). The company's external environment aspects that may affect corporate intentions in the e-business adoption process, including customer readiness, business partners' readiness and industry competition levels (García-Moreno et al., 2016; Zhu et al., 2002).

A company's network capability, which is related to innovation capability, is defined as the ability to build, and manage collaborations with other companies (Mu et al., 2017). Network capability is a dynamic capability that focuses on the specific ability to connect and create interdependence both within the organizational boundaries and between the internal and external systems of the organization, especially those related to corporate stakeholders (Battistella et al., 2017). Based on the literature review that has been described, the conceptual model is pictured in Figure 1.

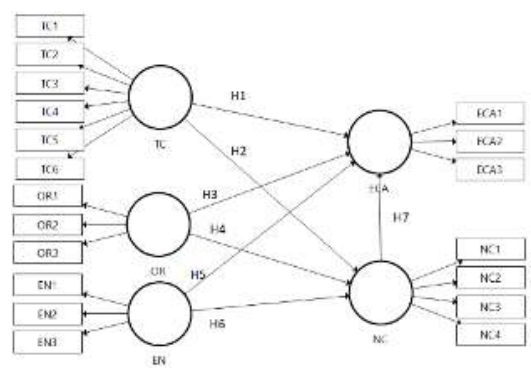

Figure 1 Conceptual Model Notes: H1: The correlation between technological context with e-commerce
acceptance is significant and positive. H2: The correlation between technological context with network capability is significant and positive. H3: The correlation between organizational context with e-commerce acceptance is significant an positive. H4: The correlation between organizational context with network capability is significant and positive. $\mathrm{H} 5$ : The correlation between environmental context with ecommerce acceptance is significant and positive. H6: The correlation between environmental context with network capability is significant and positive. H7: The correlation between network capability with e-commerce acceptance is significant and positive. 
The size of each variable is shown in Table 1.

\begin{tabular}{|c|c|c|}
\hline Variables & \multicolumn{2}{|c|}{ Indicators } \\
\hline \multirow[t]{3}{*}{ ECA } & ECA1 & $\begin{array}{l}\text { Our company intends to adopt EC with our major business } \\
\text { partners soon. }\end{array}$ \\
\hline & ECA2 & $\begin{array}{l}\text { It is likely that our company will take some steps to adopt } \\
\text { EC with our main business partners soon. }\end{array}$ \\
\hline & ECA3 & $\begin{array}{l}\text { We believe it will be beneficial for our company to adopt } \\
\text { EC with our key business partners soon. }\end{array}$ \\
\hline \multirow[t]{4}{*}{$\mathrm{NC}$} & $\mathrm{NC1}$ & $\begin{array}{l}\text { I have a system to help search for, find, and identify the } \\
\text { right networking partners }\end{array}$ \\
\hline & $\mathrm{NC2}$ & $\begin{array}{l}\text { I can design mechanisms, refine and analyze partnership } \\
\text { relationships, and dynamically integrate network activity } \\
\text { into business operational processes }\end{array}$ \\
\hline & NC3 & $\begin{array}{l}\text { I can find a partner to rely on, get the help needed from a } \\
\text { partner when needed, or refer us to a third party who can } \\
\text { help if the partner is unable to provide direct assistance }\end{array}$ \\
\hline & NC4 & $\begin{array}{l}\text { I am good at using and developing my connections and } \\
\text { networks to make things happen in my organization and } \\
\text { good at building relationships with influential individuals } \\
\text { in my organization }\end{array}$ \\
\hline \multirow[t]{6}{*}{ TC } & TC1 & $\begin{array}{l}\text { The adoption of EC will manage our business operations in } \\
\text { an efficient manner and will improve the quality of our } \\
\text { operation. }\end{array}$ \\
\hline & TC2 & The adoption of EC will offer new opportunities. \\
\hline & TC3 & $\begin{array}{l}\text { The adoption of EC is fully compatible with our current } \\
\text { business operations. }\end{array}$ \\
\hline & TC4 & The adoption of EC is in line with our business strategy. \\
\hline & TC5 & $\begin{array}{l}\text { Adoption of EC is easy to be incorporated in our business } \\
\text { operations. }\end{array}$ \\
\hline & TC6 & Adoption of EC is easy for our employees. \\
\hline \multirow[t]{3}{*}{$\mathrm{TC}$} & OR1 & $\begin{array}{l}\text { Our company management actively articulates a vision for } \\
\text { implementing EC in an organizational manner. }\end{array}$ \\
\hline & OR2 & $\begin{array}{l}\text { The management of our company is actively formulating } \\
\text { strategies for organizational EC implementation. }\end{array}$ \\
\hline & OR3 & $\begin{array}{l}\text { Our company management actively sets goals and } \\
\text { standards for monitoring EC implementation. }\end{array}$ \\
\hline \multirow[t]{3}{*}{ EN } & EN1 & $\begin{array}{l}\text { Our company thinks that EC has an influence on the } \\
\text { competition in our industry. }\end{array}$ \\
\hline & EN2 & $\begin{array}{l}\text { Our company is under pressure from competitors to adopt } \\
\text { EC. }\end{array}$ \\
\hline & EN3 & Some of our competitors have started using EC. \\
\hline
\end{tabular}

This investigation was applying a descriptiveassociative approach wherever the survey was constructed to examine the theoretical frame and foundations. This study gathered data in the cross-sectional set of time, from interviews and questionnaires. The semantic differential scale was used as a measurement of data extending from $1=$ strongly disagree to $5=$ strongly agree. The total population in this research was 150 small business Keranggan Village, based on the interview with the former of Cipta Boga cooperation. Cipta Boga cooperation has empowered small businesses in Keranggan for many years. Then, the samples were taken based on the Slovin method. The argument for taking this procedure is that a study conveyed using a planned questionnaire can provide a record of topics to respondents to collect answers. This study used convenience sampling to get the subjects followed by face-to-face data collection by the research workers. Eventually, it started in February 2020; it took 21 days to collect 100 completed, usable questionnaires. This research applies structural equation modelling using SmartPLS 3.0 for data processing. Partial least squares (PLS) examination is an elective to OLS regression, canonical relationship, or covariance-based structural equation modeling (SEM) of frameworks of independent and response factors. Structural Equation Modeling (SEM) is a second-generation multivariate data analysis method that is often used in marketing research because it can theoretically test supported linear and additive causal models.

\section{Results and Discussions}

Kampung Keranggan is a village where most of its residents work as a snack entrepreneur, be it roasted peanuts, banana chips, cassava chips, crackers, and so on. The products of this Keranggan MSMEs have been sent out of the Jabodetabek area and some have even been sent outside Java. The total number of MSMEs in Kranggan is \pm 150 MSMEs. Most of the activities carried out by the Kranggan MSMEs are still traditional, starting from processing raw materials, cooking them, packaging them, to distributing them manually. There are already products produced by MSMEs that have their own branding, but most of them are still missing and some are collected in cooperatives.

Most of the research respondents were women as business actors, namely $74 \%$. Respondents feel they need more training to apply information technology. Based on the purpose of using information technology, where respondents can choose more than one answer, the most respondents respond to marketing products and seeking inspiration for marketing promotions that are trending.

Based on the results of the collected questionnaires, the validity and reliability of the previous ones were tested to ensure that the measuring instruments were appropriate. The results of data processing show that it meets the requirements of the validity test with a loading factor above 0.7 ; $\mathrm{P}$ value below 0.05 ; and VIF below 5 .

Table 2. Validity Test (Outer Loadings) \& Collinearity Statistic

\begin{tabular}{|l|l|l|l|l|r|}
\hline Path & $\begin{array}{l}\text { Original } \\
\text { Sample (O) }\end{array}$ & STDEV & $\begin{array}{l}\text { T } \\
\text { Statistics }\end{array}$ & $\begin{array}{l}\text { P } \\
\text { Values }\end{array}$ & VIF \\
\hline ECA1 <- ECA & 0.913 & 0.020 & 46.666 & 0.000 & 2.781 \\
\hline
\end{tabular}




\begin{tabular}{|l|l|l|r|l|r|}
\hline Path & $\begin{array}{l}\text { Original } \\
\text { Sample (O) }\end{array}$ & STDEV & $\begin{array}{l}\text { T } \\
\text { Statistics }\end{array}$ & $\begin{array}{l}\text { P } \\
\text { Values }\end{array}$ & \multicolumn{1}{l|}{ VIF } \\
\hline ECA2 <- ECA & 0.859 & 0.036 & 23.813 & 0.000 & 2.214 \\
\hline ECA3 <- ECA & 0.867 & 0.024 & 36.316 & 0.000 & 1.901 \\
\hline EN1 <- EN & 0.759 & 0.050 & 15.060 & 0.000 & 1.622 \\
\hline EN2 - EN & 0.932 & 0.022 & 42.278 & 0.000 & 3.188 \\
\hline EN3 <- EN & 0.938 & 0.015 & 63.940 & 0.000 & 3.158 \\
\hline NC1 <- NC & 0.790 & 0.051 & 15.594 & 0.000 & 2.177 \\
\hline NC2 <- NC & 0.893 & 0.021 & 41.984 & 0.000 & 3.018 \\
\hline NC3 <- NC & 0.836 & 0.040 & 21.021 & 0.000 & 2.573 \\
\hline NC4 <- NC & 0.767 & 0.037 & 20.983 & 0.000 & 2.011 \\
\hline OR1 <- OR & 0.901 & 0.026 & 34.511 & 0.000 & 2.583 \\
\hline OR2 <- OR & 0.889 & 0.030 & 30.054 & 0.000 & 2.465 \\
\hline OR3 <- OR & 0.928 & 0.015 & 60.455 & 0.000 & 2.985 \\
\hline TC1 <- TC & 0.796 & 0.036 & 22.338 & 0.000 & 2.213 \\
\hline TC2 <- TC & 0.892 & 0.020 & 43.533 & 0.000 & 3.789 \\
\hline TC3 <- TC & 0.778 & 0.036 & 21.409 & 0.000 & 2.374 \\
\hline TC4 <- TC & 0.865 & 0.027 & 31.462 & 0.000 & 3.017 \\
\hline TC5 <- TC & 0.839 & 0.028 & 29.942 & 0.000 & 2.891 \\
\hline TC6 <- TC & 0.861 & 0.027 & 32.098 & 0.000 & 3.404 \\
\hline
\end{tabular}

The square root value of AVE for each latent variable is greater than the correlation value between these latent variables and other latent variables, so the instrument / questionnaire that has been designed has good discriminant validity based on the Fornell-Larcker approach.

Table 3. Construct Reliability and Validity

\begin{tabular}{|c|c|c|c|}
\hline $\begin{array}{c}\text { Cronbach's } \\
\text { Alpha }\end{array}$ & rho_A & $\begin{array}{c}\text { Composite } \\
\text { Reliability }\end{array}$ & $\begin{array}{c}\text { Average Variance } \\
\text { Extracted (AVE) }\end{array}$ \\
\hline 0.854 & 0.860 & 0.911 & 0.774 \\
\hline 0.857 & 0.925 & 0.911 & 0.775 \\
\hline 0.842 & 0.860 & 0.893 & 0.677 \\
\hline 0.891 & 0.900 & 0.932 & 0.821 \\
\hline 0.916 & 0.921 & 0.935 & 0.705 \\
\hline
\end{tabular}

Reliability testing consists of the $\mathrm{R}$ square coefficient value, composite reliability coefficient and Cronbach's alpha coefficient. The composite relaibility coefficient value must be equal to or greater than 0.7 and a Cronbach alpha value of at least 0.6. The convergent validity of a construct with a reflective indicator is evaluated by the Average Variance Extracted (AVE). The AVE value should be 0.5 or more. AVE value of 0.5 or more means that the construct can explain 50\% or more of the variance of the item (Garson, 2016).

Then the data processing was continued to the model fit test. Standardized Root Mean Square Residual (SRMR) results of data processing obtained a value of 0.086 . A value less than 0.10 or 0.08 (in a more conservative version; $\mathrm{Hu}$ and Bentler, 1999) is considered good fit. Henseler et al. (2014) introduced SRMR as a goodness of fit measure for PLS-SEM which can be used to avoid model specification errors. The data test was then continued to test the hypothesis, the results are shown in Table 3. The direct relationship test between variables shows that only the $\mathrm{EN}$ and $\mathrm{NC}$ relationships (H6) are rejected because the $\mathrm{P}$ value is higher than 0.5 .

Table 4. Mean, STDEV, T-Values, P-Values

\begin{tabular}{|l|c|c|c|c|c|}
\hline & $\begin{array}{c}\text { Original } \\
\text { Sample }\end{array}$ & $\begin{array}{c}\text { ST } \\
\text { DEV }\end{array}$ & $\begin{array}{c}\text { T } \\
\text { Stat }\end{array}$ & $\begin{array}{c}\text { P } \\
\text { Value }\end{array}$ & Outcome \\
\hline TC -> ECA & 0.205 & 0.084 & 2.440 & 0.015 & Supported \\
\hline TC -> NC & 0.722 & 0.060 & 12.096 & 0.000 & Supported \\
\hline OR -> ECA & 0.286 & 0.076 & 3.784 & 0.000 & Supported \\
\hline OR -> NC & 0.164 & 0.082 & 2.018 & 0.044 & Supported \\
\hline EN -> ECA & 0.128 & 0.062 & 2.054 & 0.041 & Supported \\
\hline EN -> NC & 0.050 & 0.060 & 0.837 & 0.403 & Rejected \\
\hline NC -> ECA & 0.386 & 0.090 & 4.284 & 0.000 & Supported \\
\hline
\end{tabular}

There is a significant direct relationship between environmental context with ecommerce acceptance, network capability with e-commerce acceptance, organizational context with e-commerce acceptance, organizational context with network capability, technological context with e-commerce acceptance, and technological context with network capability.

Then this study will examine whether the role of network capability in the relationship between TOE and e-commerce acceptance. The indirect relationship between TOE and ecommerce acceptance is shown in the Table4.

The relationship of technological context with e-commerce acceptance is mediated by significant network capability. The relationship of organizational context with e-commerce acceptance mediated by network capability is not significant. The relationship between environmental context with e-commerce acceptance mediated by network capability is not significant.

Table 5. Indirect Effects

\begin{tabular}{|l|c|c|c|c|l|}
\hline & $\begin{array}{c}\text { Original } \\
\text { Sample }\end{array}$ & $\begin{array}{c}\text { ST } \\
\text { DEV }\end{array}$ & $\begin{array}{c}\text { T } \\
\text { Stat }\end{array}$ & $\begin{array}{c}\text { P } \\
\text { Value }\end{array}$ & Outcome \\
\hline TC -> ECA & 0.279 & 0.070 & 3.960 & 0.000 & Supported \\
\hline OR -> ECA & 0.064 & 0.036 & 1.788 & 0.074 & Rejected \\
\hline EN -> ECA & 0.019 & 0.024 & 0.788 & 0.431 & Rejected \\
\hline
\end{tabular}

The full model SEM can be seen in Figure 2. The model shows the $\mathrm{P}$ value for each path and the path coefficient of the inner model. 


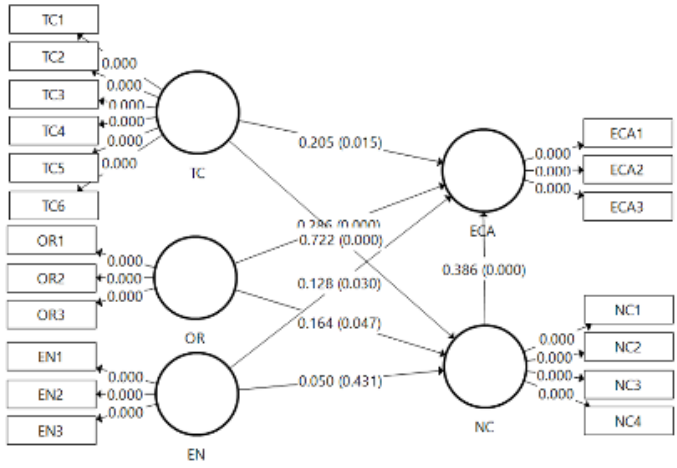

Figure 2. SEM Model

\section{Conclusions}

The results show that business actors in Keranggan intends to adopt EC with major business partners soon. Business actors in Keranggan can design mechanisms, refine and analyze partnership relationships, and dynamically integrate network activity into business operational processes (managing network relationships). Business actors in Keranggan understand that the adoption of EC will offer new opportunities. Business actors in Keranggan management actively sets goals and standards for monitoring EC implementation. Business actors in Keranggan is under pressure from competitors to adopt EC. Thus the results of this study are in line with research conducted by Alsaad et al., 2019.

The literature shows that network capability enables a company to gain access to different resources, identify opportunities, and respond quickly to rapidly changing market needs. (Battistella et al., 2017). In this case, improved internal and external communication allows the company to optimize the assimilation and distribution of knowledge and decision-making processes (Giotopoulos et al., 2017).

\section{References}

Ajzen, I. (1991). Theory of planned behavior. Academic Press. Inc. All, 50, 179-211. https://doi.org/10.1037/t15668-000

Ajzen, I., \& Madden, T. J. (1986). Prediction of goal-directed behavior: Attitudes, intentions, and perceived behavioral control. Journal of Experimental Social Psychology, 22(5), 453-474. https://doi.org/10.1016/00221031(86)90045-4
Alamro, S., \& Tarawneh, S. A. (2011). Factors affecting e-commerce adoption in Jordanian SMEs. European Journal of Scientific Research, 64(4), 497-506.

Alsaad, A., Mohamad, R., \& Ismail, N. A. (2019). The contingent role of dependency in predicting the intention to adopt B2B e-commerce. Information Technology for Development, 25(4), 686714. https://doi.org/10.1080/02681102.2018.1 476830

Battistella, C., De Toni, A. F., De Zan, G., \& Pessot, E. (2017). Cultivating business model agility through focused capabilities: A multiple case study. Journal of Business Research, 73, 65-82. https://doi.org/10.1016/j.jbusres.2016.12. 007

Bjørgen, A., Bjerkan, K. Y., \& Hjelkrem, O. A. (2019). E-groceries: Sustainable last mile distribution in city planning. Research in Transportation Economics, December, 100805. https://doi.org/10.1016/j.retrec.2019.1008 05

Chang, H. L. (2010). A roadmap to adopting emerging technology in e-business: An empirical study. In Information Systems and e-Business Management (Vol. 8, Issue 2). https://doi.org/10.1007/s10257009-0111-y

Davis, F. D. (1989). Perceived usefulness, perceived ease of use, and user acceptance of information technology. MIS Quarterly, 319-340.

DeLone, W. H., \& McLean, E. R. (2003). The DeLone and McLean model of information systems success: A ten-year update. Journal of Management Information Systems, 19(4), 9-30. https://doi.org/10.1080/07421222.2003.1 1045748

García-Moreno, M. B., García-Moreno, S., Nájera-Sánchez, J. J., \& De PablesHeredeo, C. (2016). An explanatory model of the organisational factors that explain the adoption of e-business. Journal of Industrial Engineering and Management, $\quad 9(2), \quad 547-581$. https://doi.org/10.3926/jiem.1917

Giotopoulos, I., Kontolaimou, A., Korra, E., \& Tsakanikas, A. (2017). What drives ICT 
adoption by SMEs? Evidence from a large-scale survey in Greece. Journal of Business Research, 81(December 2016), 60-69. https://doi.org/10.1016/j.jbusres.2017.08. 007

Kuan, K. K. Y., \& Chau, P. Y. K. (2001). A perception-based model for EDI adoption in small businesses using a technologyorganization-environment framework. Information and Management, 38(8), 507-521. https://doi.org/10.1016/S03787206(01)00073-8

Mu, J., Thomas, E., Peng, G., \& Di Benedetto, A. (2017). Strategic orientation and new product development performance: The role of networking capability and networking ability. Industrial Marketing Management, 64, 187-201. https://doi.org/https://doi.org/10.1016/j.in dmarman.2016.09.007

Mukred, M., Yusof, Z. M., Alotaibi, F. M., Mokhtar, U. A., \& Fauzi, F. (2019). The Key Factors in Adopting an Electronic Records Management System (ERMS) in the Educational Sector: A UTAUT-Based Framework. IEEE Access, 7, 3596335980.

https://doi.org/10.1109/ACCESS.2019.29 04617

Mukred, M., Yusof, Z. M., Mokhtar, U. A., \& Fauzi, F. (2018). Taxonomic framework for factors influencing ERMS adoption in organisations of higher professional education. Journal of Information Science, 45(2), 139-155. https://doi.org/10.1177/01655515187831 33

Olatokun, W., \& Kebonye, M. (2010). eCommerce Technology Adoption by SMEs in Botswana. International Journal of Emerging Technologies and Society, $\quad 8(1), \quad 42-56$. https://search.proquest.com/docview/612 933029? accountid $=38628$

Rogers, E. M. (2003). Diffusion Of Innovations. 1995, 512.

Sin, K. Y., Osman, A., Salahuddin, S. N.,
Abdullah, S., Lim, Y. J., \& Sim, C. L. (2016). Relative Advantage and Competitive Pressure towards Implementation of E-commerce: Overview of Small and Medium Enterprises (SMEs). Procedia Economics and Finance, 35(October 2015), 434443. https://doi.org/10.1016/s22125671(16)00054-x

Singh, J., \& Mansotra, V. (2019). Factors affecting cloud computing adoption in the Indian school education system. Education and Information Technologies, 24(4), 2453-2475. https://doi.org/10.1007/s10639-01909878-3

Tornatzky, L. G., Fleischer, M., \& Chakrabarti, A. K. (1990). Processes of technological innovation. Lexington books.

Venkatesh, V., Morris, M. G., Davis, G. B., \& Davis, F. D. (2003). User acceptance of information technology: Toward a unified view. MIS Quarterly, 425-478.

Wei, Y., Wang, C., Zhu, S., Xue, H., \& Chen, F. (2018). Online Purchase Intention of Fruits: Antecedents in an Integrated Model Based on Technology Acceptance Model and Perceived Risk Theory. Frontiers in Psychology, 9(AUG). https://doi.org/10.3389/fpsyg.2018.01521

Zhu, K., Kraemer, K. L., \& Xu, S. (2002). A Cross-Country Study of Electronic Business Adoption Using the Technology-Organization-Environment Framework. Proceedings of the International Conference on Information Systems (ICIS), 0085852, 337-348.

Ziba, P. W., \& Kang, J. (2019). Factors affecting the intention to adopt egovernment services in Malawi and the role played by donors. Information Development, 0266666919855427. https://doi.org/10.1177/02666669198554 27 